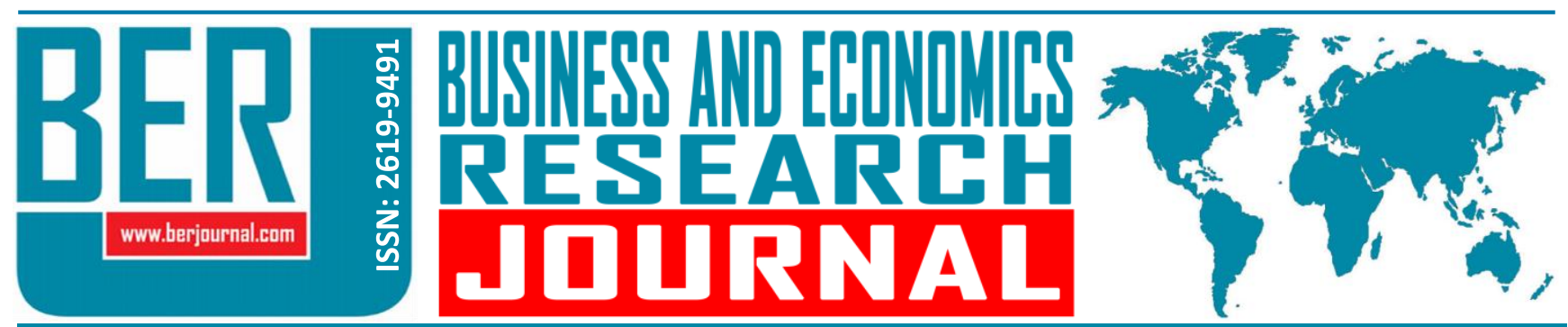

Business and Economics Research Journal Vol. 10, No. 5, 2019, pp. 1109-1125 doi: 10.20409/berj.2019.218

\title{
The Effect of Gender Identity on Consumers' Impulse Buying Behavior and The Moderating Role of Biological Sex
}

\author{
Erkan Ozdemir ${ }^{\mathrm{a}}$, Gamze Akcay ${ }^{\mathrm{b}}$
}

Abstract: Biological sex is a demographic variable whose effect has been examined in consumer researches for many years. However, the effect of gender identity, defined as the existential femininity or masculinity of individuals, has started to be examined in consumer researches since the 1960s. In the literature, there are studies investigating the effect of biological sex on consumers' impulse buying behavior. However, studies investigating the effect of gender identity on consumers' impulse buying behavior and whether this effect differs in terms of biological sex are quite limited. The aim of this study is to investigate the effect of gender identity on the consumers' impulse buying behavior and whether the effect of gender identity on the consumers' impulse buying behavior differs in terms of biological sex as a moderator variable. Research data were collected from consumers in Bursa via face to face survey method. The data obtained were evaluated by structural equation modeling to determine the effect of gender identity on impulse buying behavior. As a result of the analysis, it was found that feminine gender identity positively affected impulse buying behavior, whereas masculine gender identity did not affect impulse buying behavior. In the research, biological sex was also analyzed. As a result of the analysis, it was found that according to females, the feminine and masculine gender identity were not effective on impulse buying behavior. In addition, it was found that according to males, feminine gender identity was effective on the impulse buying behavior and masculine gender identity was not effective on impulse buying behavior.

Keywords: Biological Sex, Gender, Gender Identity, Impulse Buying Behavior, Structural Equation Modeling

JEL: M31, M30, M39

\section{Introduction}

The concept of gender identity, which has been researched in the field of psychology for many years, has started to be researched in the fields of marketing and consumer behavior in recent years. Although gender identity is closely related to "biological sex" and "gender" concepts, it is a different concept. While biological sex expresses the biological aspects of being female and male, gender expresses the psychological, social and behavioral characteristics of females and males (Pryzgoda \& Chrisler, 2000: 554). Gender identity is defined as existential femininity or masculinity of individuals (Spence, 1984: 83). In other words, gender identity expresses how individuals describe themselves according to their feminine and masculine personality traits (Palan, 2001: 1). Gender identity, which is a psychological structure, is also a social structure that reflects the culture in which we live (Kacen, 2000: 346). The meaning of being a female or a male is

a Assoc. Prof., Bursa Uludag University, Faculty of Economics and Administrative Sciences, Department of Business Administration, Bursa, Turkiye, eozdemir@uludag.edu.tr (ORCID ID: 0000-0003-0903-7638)

b PhD. Student, Bursa Uludag University, Institute of Social Sciences, Bursa, Turkiye, gamzeakcay@hotmail.com (ORCID ID: 00000001-6808-8465) 
determined by the society (Stets \& Burke, 2000: 1) and in a society, individuals with personality traits that are considered appropriate for females are called "feminine" and individuals with personality traits that are considered appropriate for males are called "masculine" (Özkan \& Lajunen, 2005: 103). For this reason, females often describe themselves as "feminine" and males often describe themselves as "masculine". Although these are traditionally accepted definitions in society, females can see themselves as "masculine" or males can see themselves as "feminine" (Stets \& Burke, 2000: 1).

Until the 1960s, the femininity and masculinity scales considered feminine and masculine personality traits as opposing poles. In other words, it is accepted that an individual can exhibit only feminine or masculine personality traits but not both feminine and masculine personality traits (Gill, Stockard, Johnson \& Williams, 1987: 375). Opposing this view, Bem (1974) developed the Bem Sex-Role Inventory (BSRI) and evaluated individuals in three dimensions as feminine (high femininity, low masculinity), masculine (high masculinity, low femininity) and androgynous (high femininity, high masculinity). In the following years, this categorization was extended and individuals were evaluated in four dimensions as feminine (high femininity, low masculinity), masculine (high masculinity, low femininity), androgynous (high femininity, high masculinity) and undifferentiated (low femininity, low masculinity) (Bem, 1977; Spence, Helmreich \& Stapp, 1975). However; in this study, only "femininity" and "masculinity" dimensions of gender identity were examined.

Impulse buying has been researched in the marketing literature for many years and the first researches on impulse buying date back to the 1950s. In these researches, impulse buying was defined as an unplanned buying (Clover, 1950; Stern; 1962). For instance, Stern (1962) defined impulse buying behavior as a situation involving all purchases made by the consumer without making plans before shopping and distinguished it into four categories. These categories are pure impulse buying, reminder impulse buying, suggestion impulse buying and planned impulse buying. In the pure impulse buying type, the consumer buys a product that differs from routine buying habits. In the reminder impulse buying type, when a consumer sees a product during shopping, he/she remembers that he/she needs it and buys it. In the suggestion impulse buying type, the consumer buys the product when he/she first sees the product, although he/she has no knowledge about the product. In the planned impulse buying type, a consumer enters the store with the intention of buying certain products but buys different products with the effect of discounts, etc.

In later years, the scope of impulse buying was expanded and researchers focused on the personal characteristics, psychological and emotional states of consumers (Rook an\& Hoch, 1985; Rook, 1987; Rook \& Gardner; 1993). One of these researchers Rook (1987) defined impulse buying behavior as a result of the consumer experiencing a sudden, strong and persistent urge to buy a product immediately. Impulse buying behavior was defined by Rook and Fisher (1995) as a tendency of the consumer to buy a product spontaneously, unreflectively, immediately, and kinetically. Beatty and Ferrell (1998) defined impulse buying as a sudden purchase without the pre-shopping intention of consumers to buy a specific product category or to meet a specific need.

In the consumer behavior literature, there are studies investigating the effect of biological sex on consumers' impulse buying behavior (Ghani \& Jan, 2011; Ekeng, Lifu \& Asinya, 2012; Khan, Hui, Chen \& Hoe, 2016; Sangalang, Siochi \& Plaza, 2017). However; in recent years, the importance of gender identity, which expresses masculinity and femininity, is emphasized as much as biological sex. For many years, traditional approaches have argued that females should exhibit feminine personality traits and males masculine personality traits in accordance with biological sex. However; nowadays, females have started to exhibit more masculine personality traits, attitudes, and behaviors, and males have started to exhibit more feminine personality traits, attitudes, and behaviors due to social and cultural changes (Çabuk \& Köksal Araç, 2013: 28). It is thought that these changes in the gender identity will affect the consumers' impulse buying behavior and the studies investigating the effect of the gender identity on the consumers' impulse buying behavior should be included in the literature.

This study aims to reveal the effect of gender identity on the consumers' impulse buying behavior and whether the effect of gender identity on the consumers' impulse buying behavior differs in terms of 
biological sex as a moderator variable. It is thought that this study will contribute to the literature in terms of theoretical and practical aspects.

Within the scope of the study, firstly information about gender identity and impulse buying behavior was given, and literature was examined and gender studies on impulse buying behavior were examined. Then, the methodology of the research and the findings obtained as a result of the analysis were given. In the conclusion part, the contributions of the study to the theoretical and practical aspects were evaluated and suggestions for future researches and businesses were presented.

\section{Literature Review and Research Hypotheses}

\subsection{Gender Identity}

When the literature on consumer behavior is examined, it is seen that various terms such as "sexrole self-concept" (Golden, Allison \& Clee, 1979; Allison, Golden, Mullet \& Coogan, 1980; Stern, 1988) and "sex/gender-role identity" (Kahle \& Homer, 1985; Jaffe \& Berger, 1988) have been used instead of gender identity. However; in recent studies (Palan, 2001; Martin \& Gnoth, 2009; Ye \& Robertson, 2012; Çabuk \& Köksal Araç, 2013), the term "gender identity" has been frequently used. Similarly, the term "gender identity" has been used in this study. However, in the literature review part of this study, the terms used instead of gender identity have been expressed as used in the researches.

The gender identity, which began to be studied in the psychology literature in the 1930s, was the subject of consumer research for the first time in the 1960s. Scales developed to measure gender identity in the 1970s began to be used in consumer research. Since the 1990s, gender identity has been frequently investigated in consumer research (Palan, 2001: 1). In some of these studies, the relationship between gender identity and product or brand preferences of consumers has been examined. For instance, Aiken (1963) investigated the relationship between factors affecting the consumers' choice of dress and personality variables. As a result of the research, a positive relationship was found between femininity and interest in the dress, decoration in the dress and conformity in the dress. In another research, Vitz and Johnston (1965) investigated whether the image of the cigarette brand preferred by masculine smokers is masculine. As a result of the research, a positive relationship was found between the masculinity of smokers and the masculine image of the preferred cigarette brand. Kahle and Homer (1985), who examined the effect of sexrole identity on consumers' preferred foods at lunch, concluded that sex-role identity was only effective on a few food preferences. Worth, Smith, and Mackie (1992) aimed to find the relationship between consumers' self-perceived schema (femininity/masculinity) and the feminine or masculine image of products. As a result of the research, it was seen that regardless of their biological sex, masculine consumers preferred a product with a masculine image and feminine consumers preferred a product with a feminine image.

Fischer and Arnold (1990), who investigated the relationship between gender identity and consumers' shopping for Christmas gift, found that more feminine consumers were more involved in shopping for Christmas gift. In another study, Palan, Areni, and Kiecker (2001) examined the relationship between gender identity and consumers' gift shopping. Research findings showed that feminine consumers were more individual-focused and masculine consumers were more object-focused in gift shopping. Another finding of the study was that masculine consumers remembered their gift-giving experiences more than feminine consumers. Kılıçer, Boyraz, and Tüzemen (2016) investigated the effect of gender role identity on the consumers' gift-buying behavior. As a result of the research, it was found that androgynous consumers bought fewer gifts and undifferentiated consumers bought more gifts.

Martin and Gnoth (2009) investigated male consumers' responses to the gender identity of male models in print advertisements. As a result of the research, it was seen that male consumers preferred models reflecting their gender identity. In the study of Yağcı and ilarslan (2010), the effect of gender role identity on consumers' attitudes towards advertising and consumers' buying behaviors was examined. As a result of the research, it was found that feminine consumers reacted positively to feminine advertisements 
and bought products with feminine advertisements, while masculine consumers reacted positively to masculine advertisements and bought products with masculine advertisements.

Ye and Robertson (2012), who investigated the effect of gender identity on product involvement and brand loyalty in terms of generation $Y$ consumers, found that femininity had a positive effect on product involvement and masculinity had a positive effect on brand loyalty. In the conceptual study conducted by Çabuk and Köksal Araç (2013), gender identity was examined as a psychographic market segmentation variable in consumption researches.

\subsection{Impulse Buying Behavior}

In the marketing literature, early research on impulse buying behavior focused on defining and explaining the concept (Clover, 1950; Stern, 1962; Rook \& Hoch; 1985; Rook, 1987). In recent years, researches on impulse buying behavior have generally investigated the factors affecting impulse buying behavior. Different classifications were made by the researchers regarding these factors. In this study, the factors affecting impulse buying behavior were classified as "external factors", "internal factors", "situational factors related to consumers" and "demographic characteristics of consumers".

Some of the impulse buying behavior researches investigated the effects of external factors such as store environment, promotional activities, staff's behavior, product characteristics on impulse buying behavior. For instance, Virvilaite, Saladiene, and Bagdonaite (2009) investigated the factors affecting impulse buying behavior and found that product characteristics (price, etc.) and characteristics of store environment (store type, store layout, staff, etc.) had an effect on impulse buying behavior. Another researcher Tinne (2011), examined the factors affecting impulse buying behavior on superstores. As a result of the research, it was found that price strategies (the price of product, etc.), store characteristics (display of product, behavior of salesperson, etc.), situational factors (popularity of product, etc.) and promotional activities (specific brand offer, advertisements, etc.) had an effect on impulse buying behavior. Rasheed, Yaqup, and Baig (2017) who investigated the factors affecting the impulse buying behavior of consumers in shopping centers concluded that store atmosphere, payment facilities, point of purchase display and promotional activities had an effect on impulse buying behavior. Husnain, Rehman, Syed and Akhtar (2019) examined the effect of in-store factors on the generation $Y$ consumers' impulse buying behavior in small cities and found that in-store factors such as store environment, sales promotions, friendly store employees had a positive effect on impulse buying behavior.

Mehta and Chugan (2013) aimed to determine the effect of visual merchandising dimensions on impulse buying behavior. They found a positive relationship between impulse buying behavior and window display, floor merchandising, promotional signage and a negative relationship between impulse buying behavior and in-store form/mannequin display. Similarly, Gudonaviciene and Alijosiene (2015) who investigated the effect of visual merchandising dimensions on impulse buying in clothing and footwear stores found that visual merchandising dimensions that most affect impulse buying behavior were "window displays" and "in-store design".

Some of the impulse buying behavior researches investigated the effects of internal factors such as mood, emotional states, impulsiveness, hedonism on impulse buying behavior. In one of these studies, Rook and Gardner (1993) examined the effect of positive and negative moods of consumers on impulse buying behavior. As a result of the study, it was found that consumers with positive moods are more prone to impulse buying behavior than consumers with negative moods. Beatty and Ferrell (1998) who investigated the antecedents of impulse buying behavior found that the positive mood of consumers led to impulse buying behavior by creating the urge for impulse buying. However, the negative mood had no such effect. Graa and Dani-elKebir (2012) aimed to reveal the effect of consumers' emotional states on impulse buying behavior. As a result of the study, it was found that the feelings of pleasure and arousal of consumers had a positive effect on the impulse buying behavior and dominance had a negative effect on impulse buying behavior.

Yu and Bastin (2010) investigated the relationship between hedonic shopping value and impulse buying intention. As a result of the research, it was found that hedonic shopping value was positively related 
to impulse buying intention. This finding shows that hedonic experiences may create more impulse buying behavior. Gunawan (2016) who examined the relationship between hedonic consumption and impulse buying behavior found a positive relationship between hedonic consumption and impulse buying behavior. Türk (2018) investigated the effect of hedonic and utilitarian consumption tendencies on impulse buying behavior. The results of the research showed that hedonic and utilitarian consumption tendencies had a positive effect on the impulse buying behavior and hedonic consumption led to more impulse buying behavior than utilitarian consumption.

Some of the impulse buying behavior researches investigated the effects of situational factors related to consumers such as time availability, money availability, family influence on impulse buying behavior. Beatty and Ferrell (1998) found that money availability created positive emotions for consumers and those positive emotions produced an urge to buy impulsively. In addition, time availability positively affected instore browsing. Therefore, the urges to buy impulsively were produced. Virvilaite et al. (2009) who proposed a theoretical model of impulse buying behavior found that situational factors related to consumers such as consumer time, influence group had an effect on impulse buying behavior. Husnain et al. (2019) examined the generation $Y$ consumers' impulse buying behavior in small cities and found that time availability and family influence factors positively affect impulse buying behavior but money availability negatively.

In literature, another factor affecting the consumers' impulse buying behavior was the demographic characteristics of consumers. According to related studies, the most investigated demographic characteristic of the effect on the consumers' impulse buying behavior was gender. Studies investigating the consumers' impulse buying behavior in terms of gender are discussed in detail below under a separate heading.

\subsection{Gender and Impulse Buying Behavior}

When the studies investigating the consumers' impulse buying behavior in terms of gender were examined, it was seen that these studies generally focused on "biological sex". Some of these studies aimed to reveal the effect of biological sex on the consumers' impulse buying behavior. In one of the related studies, Ghani and Jan (2011) found that biological sex had no effect on the consumers' impulse buying behavior. In the study of Ekeng et al. (2012), it was found that biological sex had an effect on the consumers' impulse buying behavior and that females had more impulse buying behavior than males. Khan et al. (2016) investigated the effect of biological sex on generation $Y$ consumers' impulse buying behavior for fashion apparel products. The results of the study showed that biological sex affected generation $Y$ consumers' impulse buying behavior for fashion apparel products. Sangalang et al. (2017) found that biological sex did not affect consumers' impulse buying behavior.

In some of the studies examining consumers' impulse buying behavior in terms of gender, it was aimed to reveal whether the consumers' impulse buying behavior differed according to biological sex. For instance, Akagün Ergin and Özdemir Akbay (2011) investigated whether the consumers' impulse buying behavior in apparel and food product categories differed by biological sex. As a result of the study, it was found that females exhibited more impulse buying behavior than males. Rana and Tirthani (2012) investigated whether the consumers' impulse buying behavior for readymade garment products differed according to biological sex. They found that the consumers' impulse buying behavior did not differ according to biological sex. In the study of Awan and Abbas (2015), it was investigated whether the consumers' impulse buying behavior differed according to biological sex and as a result of the research, it was found that males made more impulse buying than females. Özgüven Tayfun (2015) who investigated whether the consumers' impulse buying behavior in grocery shopping differed according to biological sex found that females made more impulse buying than males. In another study, Gandhi, Vajpayee, and Gautam (2015) examined whether the consumers' impulse buying behavior for beverage products differed according to biological sex. As a result of the study, it was found that females exhibited more impulse buying behavior than males.

As seen in the literature review above, there are studies investigating the effect of biological sex on the consumers' impulse buying behavior, but there are no studies investigating the effect of gender identity on the consumers' impulse buying behavior and whether this effect differs according to biological sex. Based 
on the literature review, the following hypotheses have been created to determine the effects of feminine and masculine gender identity on consumers' impulse buying behavior and to reveal whether these effects differ significantly according to biological sex.

$\boldsymbol{H}_{1}$ : Feminine gender identity has a positive effect on consumers's impulse buying behavior.

$\boldsymbol{H}_{2}$ : Masculine gender identity has a positive effect on consumers's impulse buying behavior.

$\boldsymbol{H}_{3}$ : The effects of feminine and masculine gender identity on consumers's impulse buying behavior differ significantly according to the biological sex of the respondents.

$\boldsymbol{H}_{3 a}$ : The effects of feminine gender identity on consumers's impulse buying behavior differ significantly according to the biological sex of the respondents.

$\boldsymbol{H}_{3 b}$ : The effects of masculine gender identity on consumers's impulse buying behavior differ significantly according to the biological sex of the respondents.

The research model created based on the literature review is shown in Figure 1.

Figure 1. Research Model

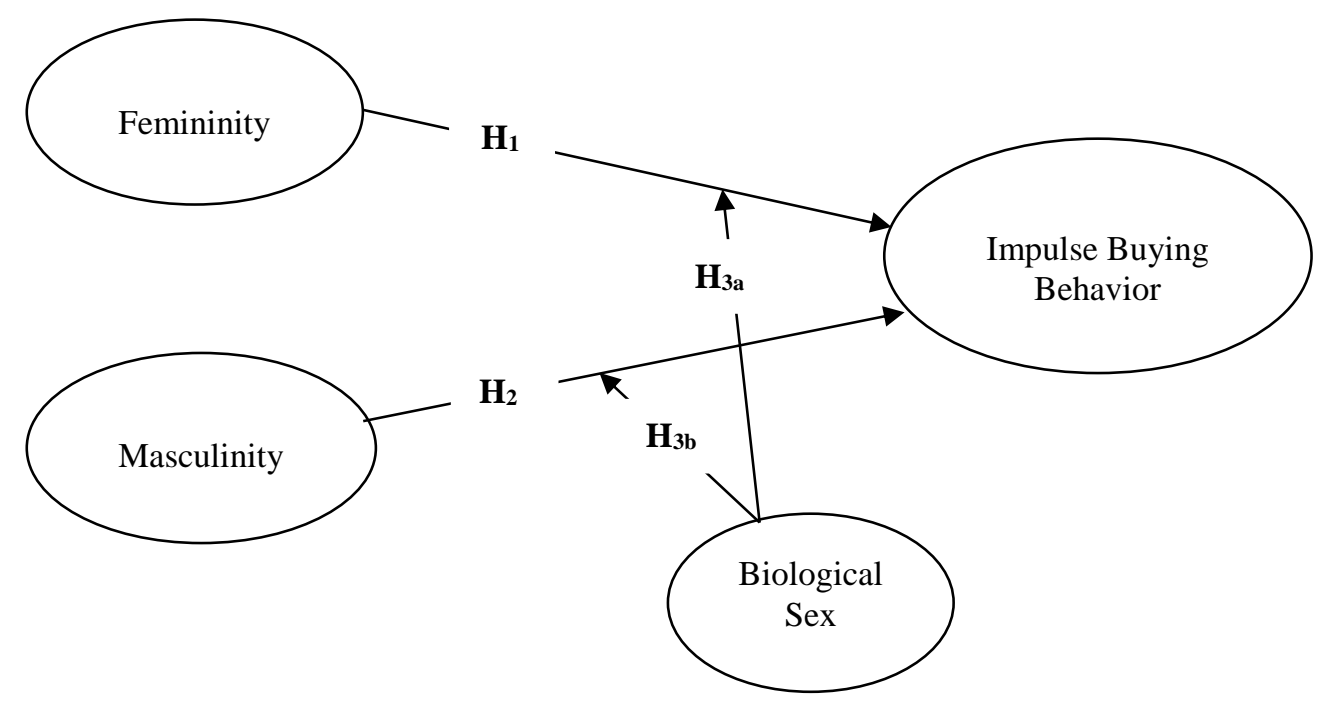

\section{Research Methodology}

The aim of the study is to determine the effects of femininity and masculinity dimensions of gender identity on the consumers' impulse buying behavior and whether these effects differ significantly according to biological sex. In the study carried out on the consumers in Bursa, the convenience sampling method was used by taking into consideration the limiting factors such as cost and time.

Research data were collected between 01-31 August 2018 by using face to face survey method. As a result of the study, 426 questionnaires were obtained and the data were analyzed using IBM SPSS 23 and Smart PLS 3.2.8 package program.

The questionnaire used in the research consists of three parts. The first part consists of 5 categorical questions to determine the demographic characteristics of the participants. In the following two-part, the Likert scale was used to measure the consumers' gender identity and impulse buying behavior.

The short form of the Bem Sex-Role Inventory (BSRI) developed by Bem (1981) was used to determine the consumers' gender identity. The original form of BSRI including 60 personality traits consists of Femininity scale (20 feminine personality traits), Masculinity scale (20 masculine personality traits) and Social Desirability scale (20 neutral personality traits) (Bem, 1974). Similarly, the short form of BSRI including 30 
personality traits consists of Femininity scale (10 feminine personality traits), Masculinity scale (10 masculine personality traits) and Social Desirability scale (10 neutral personality traits) (Bem, 1981). In research, Femininity scale including 10 feminine personality traits and Masculinity scale including 10 masculine personality traits were used in the short form of BSRI to shorten the time to answer the questionnaire. The validity and reliability of the short form of BSRI were investigated by Özkan and Lajunen (2005) on the university students of Middle East Technical University. As a result of the research, the scale was accepted as valid and reliable in Turkey.

A scale including 5 items and developed by Weun et al. (1997) was used to measure the consumers' impulse buying behavior. Validity and reliability of this scale were investigated by Torlak and Tiltay (2010). As a result of the study, the scale was accepted as valid and reliable in Turkey.

\section{Data Analysis and Findings}

In the analysis of data, firstly, frequency analysis was performed to determine the demographic characteristics of the participants. Then, the validity and reliability of the scale dimensions used in the analyzes were analyzed. Finally, the proposed research model was tested by Structural Equation Modeling (SEM) using Smart PLS 3.2.8.

\subsection{Findings on Demographic Characteristics of the Participants}

The data related to the demographic characteristics of the participants were examined by frequency analysis. The data related to the demographic characteristics of the participants are shown in Table 1 below.

Table 1. Demographic Characteristics of the Participants

\begin{tabular}{|c|c|c|c|}
\hline \multicolumn{2}{|c|}{ Demographic Characteristics } & N & $\%$ \\
\hline \multirow{3}{*}{ Biological Sex } & Female & 184 & 43.2 \\
\cline { 2 - 4 } & Male & 242 & 56.8 \\
\hline \multirow{3}{*}{ Age } & $\leq 20$ & 14 & 3.3 \\
\cline { 2 - 4 } & $21-30$ & 224 & 52.6 \\
\cline { 2 - 4 } & $31-40$ & 131 & 30.8 \\
\cline { 2 - 4 } & $41-50$ & 48 & 11.3 \\
\hline \multirow{3}{*}{ Education } & $\geq 51$ & 9 & 2.1 \\
\cline { 2 - 4 } & Primary Education & 6 & 1.4 \\
\cline { 2 - 4 } & High School & 86 & 20.2 \\
\cline { 2 - 4 } & Undergraduate & 232 & 54.5 \\
\cline { 2 - 4 } & Master Degree & 89 & 20.9 \\
\hline \multirow{3}{*}{ Marital Status } & Doctoral Degree & 13 & 3.1 \\
\cline { 2 - 4 } & Single & 212 & 49.8 \\
\hline \multirow{3}{*}{ Income (Turkish Lira / TL) } & Married & 214 & 50.3 \\
\hline & $\leq 2000 \mathrm{TL}$ & 83 & 19.5 \\
\cline { 2 - 4 } & 2001 TL - 3000 TL & 122 & 28.6 \\
\hline & 3001 TL - 4000 TL & 132 & 31.0 \\
\cline { 2 - 4 } & 4001 TL - 5000 TL & 70 & 16.4 \\
\cline { 2 - 4 } & $\geq 5001$ TL & 19 & 4.5 \\
\hline & & 426 & 100 \\
\hline
\end{tabular}


As shown in Table 1 above, the majority of the participants were male (56.8\%) and between 21-30 years old $(52.6 \%)$ consumers. In terms of education, more than half of the participants $(54.5 \%)$ were university graduates. When the marital status of the participants is examined, it is seen that married participants (50.3\%) were more than single participants (49.8\%). In terms of income, more than half of the participants (59.6\%) had a monthly income of between 2001 - 4000 Turkish Liras.

Structural equation modeling was used to test the research model. Structural equation modeling is a very popular statistical technique in marketing (Henseler, 2017: 361). In this study, PLS-SEM was used as the variance-based structural equation modeling technique which is one of the structural equation modeling techniques to test the research model.

PLS-SEM technique has features such as nonparametric structure (not requiring normal distribution), handling complex models, statistical power, working with small samples and not requiring goodness-of-fit values according to covariance-based SEM techniques (Sarstedt, Ringle \& Hair, 2017: 11-14). In this study, sufficient sample size was reached. However, since no normal distribution was required, PLS-SEM technique was preferred in this study. The validity and reliability of the scale dimensions used in the analyzes and the test of the proposed research model were analyzed using Smart PLS 3.2.8 package program.

\subsection{Measurement Model Results}

Internal consistency reliability, convergent validity and discriminant validity of the data were analyzed within the scope of validity and reliability analysis of the structures included in the research. For internal consistency reliability, Cronbach's Alpha and Composite Reliability (CR) values were calculated. The average variance values explained by factor loadings (AVE=Average Variance Extracted) were used for the analysis of convergent validity. The Cronbach's Alpha and Composite Reliability (CR) values are used to measure the consistency of items in the scale, while the Average Variance Extracted (AVE) value is used to see the measure of the convergence between certain items representing the latent structure.

According to Hair, Black, Babin, and Anderson (2014: 618-619), factor loadings should be over 0.50, Cronbach's Alpha and Composite Reliability (CR) values should be over 0.70 , and the Average Variance Extracted (AVE) should be over 0.50. Table 2 below shows the measurement model analysis results of the structures in the research model.

Table 2. Results of Measurement Model

\begin{tabular}{|c|c|c|c|c|c|}
\hline Structure & Items & $\begin{array}{l}\text { Factor } \\
\text { Loadings }\end{array}$ & $\begin{array}{c}\text { Cronbach's } \\
\text { Alpha }\end{array}$ & $\begin{array}{c}\text { Composite } \\
\text { Reliability } \\
\text { (CR) }\end{array}$ & $\begin{array}{c}\text { Average } \\
\text { Variance } \\
\text { Extracted } \\
\text { (AVE) }\end{array}$ \\
\hline \multirow{6}{*}{ Femininity } & Femininity 1 & 0.624 & \multirow{6}{*}{0.809} & \multirow{6}{*}{0.860} & \multirow{6}{*}{0.509} \\
\hline & Femininity 10 & 0.675 & & & \\
\hline & Femininity 2 & 0.760 & & & \\
\hline & Femininity 6 & 0.619 & & & \\
\hline & Femininity 7 & 0.780 & & & \\
\hline & Femininity 8 & 0.800 & & & \\
\hline \multirow{4}{*}{ Masculinity } & Masculinity 4 & 0.903 & \multirow{4}{*}{0.752} & \multirow{4}{*}{0.821} & \multirow{4}{*}{0.540} \\
\hline & Masculinity 5 & 0.608 & & & \\
\hline & Masculinity 6 & 0.701 & & & \\
\hline & Masculinity 8 & 0.695 & & & \\
\hline \multirow{5}{*}{$\begin{array}{c}\text { Impulse Buying } \\
\text { Behavior }\end{array}$} & Impulse BB 1 & 0.860 & \multirow{5}{*}{0.912} & \multirow{5}{*}{0.934} & \multirow{5}{*}{0.739} \\
\hline & Impulse BB 2 & 0.886 & & & \\
\hline & Impulse BB 3 & 0.875 & & & \\
\hline & Impulse BB 4 & 0.879 & & & \\
\hline & Impulse BB 5 & 0.796 & & & \\
\hline
\end{tabular}


When the above Table 2 is examined, it is seen that the factor loadings of all items are between 0.608 and 0.903. In other words, the factor loadings of all items are above the threshold value of 0.50. During the analysis, Femininity 3, Femininity 4, Femininity 5, Femininity 9, Masculinity 1, Masculinity 2, Masculinity 3, Masculinity 7, Masculinity 9 and Masculinity 10 items with factor loading less than 0.50 were excluded from the analysis. Therefore, the analysis of the measurement model and the structural equation model after that were carried out using 15 items with a factor loading above 0.50 . When Table 2 is examined, it is seen that the Cronbach's Alpha coefficients of the structures are between 0.752 and 0.912; and the Composite Reliability (CR) values are between 0.821 and 0.934 . These values, which are above the threshold values in the literature, indicate that the internal consistency reliability of the scale is achieved.

Average Variance Extracted (AVE) values of the structures are between 0.509 and 0.739 . These values are above the threshold value of 0.50 . Therefore, these values indicate that convergent validity is achieved.

In this study, the criteria proposed by Fornell and Larcker (1981) and Henseler, Ringle, and Sarstedt (2015: 116) were used to determine the discriminant validity. The discriminant validity is used to measure the degree of differences between two conceptually similar structures. According to Fornell and Larcker (1981) criteria, the square roots of the AVE values of the structures in the research should be higher than the correlations between these structures. Table 3 below shows the results of the discriminant validity analysis according to Fornell and Larcker (1981) criteria.

Table 3. Results of the Discriminant Validity Analysis by Fornell - Larcker Criterion

\begin{tabular}{|l|c|c|c|}
\hline & Masculinity & Femininity & $\begin{array}{c}\text { Impulse Buying } \\
\text { Behavior }\end{array}$ \\
\hline Masculinity & $\mathbf{0 . 7 3 5}$ & & \\
\hline Femininity & 0.092 & $\mathbf{0 . 7 1 3}$ & \\
\hline Impulse Buying Behavior & -0.050 & 0.177 & $\mathbf{0 . 8 6 0}$ \\
\hline
\end{tabular}

Note: The bolded values in the table are the square roots of the AVE values.

When Table 3 is examined, it is seen that the square root of the explained average variance (AVE) value of each structure is higher than the correlation with other structures.

According to the Henseler et al.'s (2015) criterion, HTMT (Heterotrait-Monotrait Ratio) expresses the ratio of the mean of the correlations of the items of all variables in the research (the heterotraitheteromethod correlations) to the geometric means of the correlations of the items of the same variable (the monotrait-heteromethod correlations). Henseler et al. (2015) stated that the HTMT value should be below 0.85 , but that the HTMT value among the structures with similar content can be up to 0.90 . Table 4 below shows the results of the discriminant validity analysis according to the HTMT criteria.

Table 4. Results of the Discriminant Validity Analysis by HTMT Criterion

\begin{tabular}{|l|c|c|c|}
\hline & Masculinity & Femininity & $\begin{array}{c}\text { Impulse Buying } \\
\text { Behavior }\end{array}$ \\
\hline Masculinity & & & \\
\hline Femininity & 0.129 & & \\
\hline Impulse Buying Behavior & 0.057 & 0.191 & \\
\hline
\end{tabular}

When Table 4 is examined, it is seen that HTMT values are below the threshold value of 0.85 . When Table 3 and Table 4 are evaluated together, it can be stated that the discriminant validity between the 
structures included in this research is achieved. As a result, the structures in the study were found suitable for structural equation analysis.

\subsection{Testing the Research Model}

After analyzing the validity and reliability of the research model, the proposed research model was examined with the structural equation model analysis in order to test the hypotheses. While the femininity and masculinity dimensions in the model constitute exogenous variables affecting impulse buying behavior, impulse buying behavior constitutes the endogenous variable. Partial least-squares path analysis (PLS-SEM) was used to analyze the research model. In the evaluation of the model, basic measurements such as $R^{2}, \beta$, and $t$-values ( $t$ value $>1.96$ ) and predictive power $\left(Q^{2}\right)$ and effect magnitude $\left(f^{2}\right)$ values were examined. PLS algorithm was used for the measurement model and Blindfolding analysis was used to calculate the predictive power $\left(Q^{2}\right)$ value. In order to measure the significance of PLS path coefficients, $t$-values were recalculated by taking 5000 sub-samples from the sample using the bootstrapping technique. Figure 2 shows the results of the structural equation modeling (PLS-SEM) analysis.

Figure 2. Results of the Structural Model

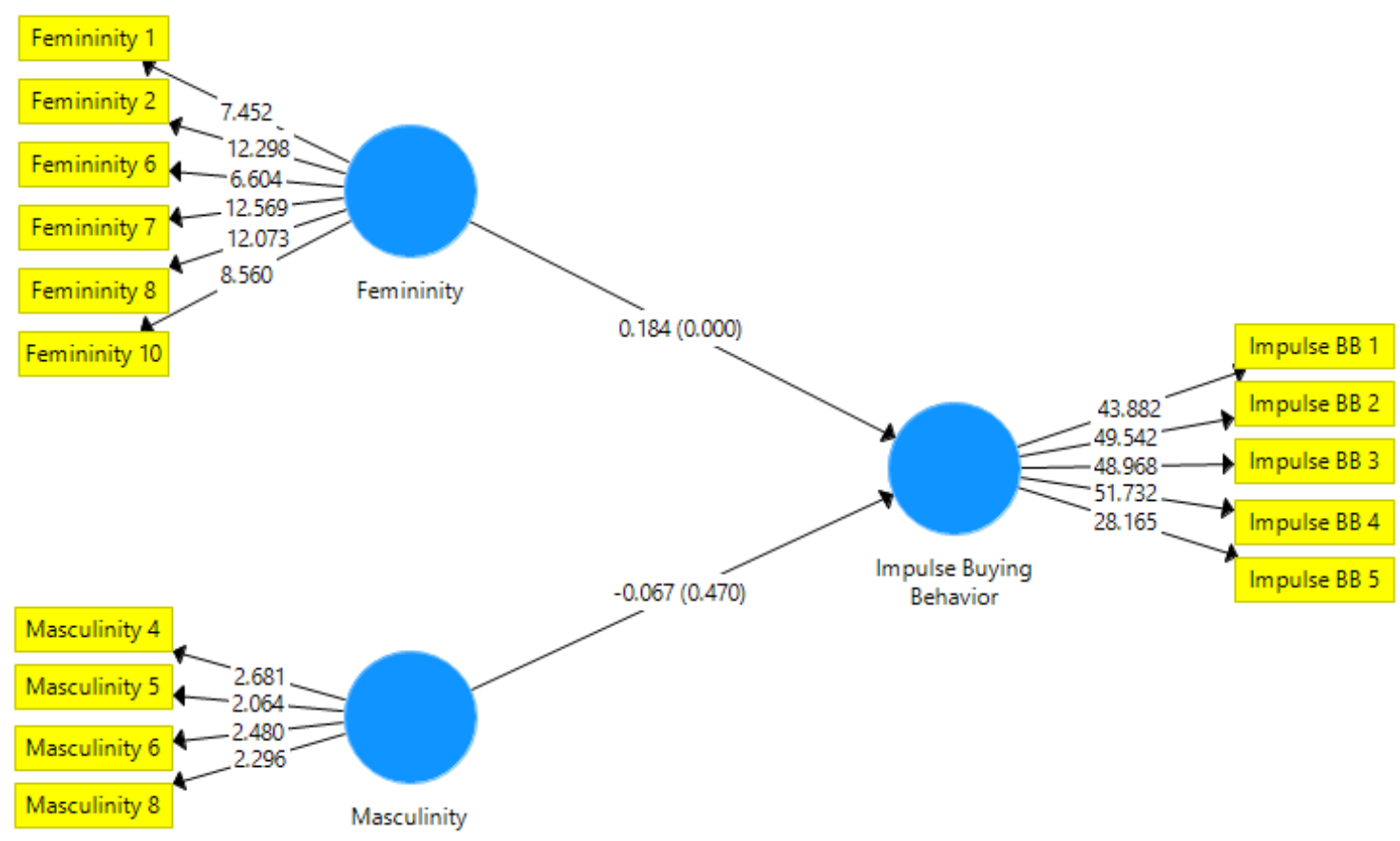

The results of the structural equation modeling analysis are shown in Table 5 below.

Table 5. The Results of the Structural Equation Modeling Analysis

\begin{tabular}{|c|c|c|c|c|c|c|c|c|c|c|}
\hline 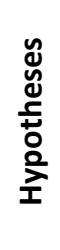 & Paths & 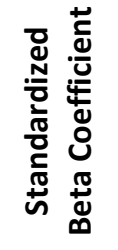 & 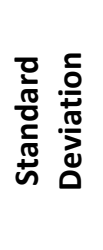 & 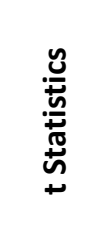 & $\sum_{\frac{2}{2}}^{\frac{0}{2}}$ & $\approx$ & ๘ & ชั & $\stackrel{u}{\supset}$ & 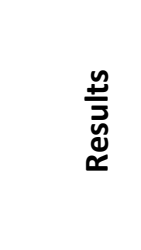 \\
\hline $\mathbf{H}_{1}$ & $\begin{array}{l}\text { Femininity } \rightarrow \\
\text { Impulse Buying } \\
\text { Behavior }\end{array}$ & 0.184 & 0.043 & 4.275 & 0.000 & \multirow{2}{*}{0.036} & 0.035 & \multirow{2}{*}{0.016} & 1.009 & Accepted \\
\hline $\mathbf{H}_{2}$ & $\begin{array}{l}\text { Masculinity } \rightarrow \\
\text { Impulse Buying } \\
\text { Behavior }\end{array}$ & -0.067 & 0.093 & 0.723 & 0.470 & & 0.005 & & 1.009 & Rejected \\
\hline
\end{tabular}


When Table 5 above is examined, it is seen that the significance value of the $\mathrm{H}_{1}$ hypothesis, which expresses the effect of feminine gender identity on impulse buying behavior, is $p=0.000(p<0.05)$. Therefore, the proposed $\mathrm{H}_{1}$ hypothesis is supported. When the standardized $\beta$ coefficient, which indicates the effect rate of this hypothesis, is examined, it is seen that feminine gender identity has an effect at the level of 0.184 on impulse buying behavior. On the other hand, the effect of masculine gender identity on impulse buying behavior, which expresses the hypothesis $\mathrm{H}_{2}$, is -0.067 . However, since the significance value of the $\mathrm{H}_{2}$ hypothesis is $p=0.470(p>0.05)$, this effect is not significant. Therefore, the proposed $\mathrm{H}_{2}$ hypothesis is not supported.

When Table 5 is examined, it is seen that VIF (Variance Inflation Factor) values of all variables are below the threshold value of 5 (Garson, 2016: 77; Ali, Rasoolimanesh, Sarstedt, Ringle \& Ryu, 2018: 529). Therefore, it can be stated that there is no linearity problem between variables.

In the analysis of the internal model, Hair, Hult, Ringle, and Sarstedt (2017) suggest that the $\mathrm{R}^{2}$ value, which expresses the explained variance of each external latent variable, is also analyzed. When the $R^{2}$ values of the model are examined, it is seen that the femininity and masculinity dimensions explain the impulse buying behavior by approximately $4 \%$.

Hair et al. (2017) stated that in addition to $R^{2}, f^{2}$ and $Q^{2}$ values should be examined in the evaluation of the reflective internal model. The $\mathrm{f}^{2}$ value, expressed as the effect magnitude, refers to the calculation of the increase in $\mathrm{R}^{2}$, based on the variance ratio of the unexplained portion of the external latent variable. The effect magnitude of the prediction structures is evaluated by looking at $\mathrm{f}^{2}$ values. In Cohen's study (1988), $\mathrm{f}^{2}$ values in the range of $0.02,0.15$ and 0.35 are expressed as small, medium and large effect dimensions, respectively. In other words, if $\mathrm{f}^{2}$ values are between $0.02-0.15$ small; between $0.15-0.35$ medium; 0.35 and above is expressed as a high effect rate. When Table 5 is examined, it is seen that the femininity (0.035) and masculinity (0.005) dimensions have a low effect on impulse buying behavior. The $Q^{2}$ value obtained from the blindfolding analysis evaluates the predictive validity of the model (Ali, Amin \& Cobanoglu, 2016: 463). $Q^{2}$, which is a re-use technique of the predictive sample, is an effective criterion in determining the estimated effectiveness level. In order for the model to have a predictive fit, it should be $Q^{2}>0$ (Peng \& Lai, 2012: 473). When Table 5 is examined, the $Q^{2}$ value of the femininity and masculinity dimensions was found 0.016 . These results show that the model has an predictive validity.

\subsection{Multiple Group Analysis}

Another aim of this study is to determine whether the effects of femininity and masculinity dimensions on consumers' impulse buying behavior differ in terms of biological sex. In other words, to determine whether the biological sex variable has a moderating role in the proposed structural model. The results of the multi-group analysis in which biological sex is considered as a moderator variable are given in Table 6, figure 3 and figure 4 below.

As shown in Figures 3 and 4, there are differences in the standardized effect coefficients of the proposed structural equation model. Figure 3 shows the effects of femininity and masculinity dimensions on impulse buying behavior according to female respondents.

When Figure 3 is examined, it is seen that the femininity dimension has an effect on impulse buying behavior (-0.165). When Table 6 is examined, it is seen that this effect is not significant since the significance value is $p=0.386$ ( $p>0.05)$. Similarly, in Figure 3 , it is seen that the masculinity dimension has an effect on impulse buying behavior (0.181). When Table 6 is examined, it is seen that this effect is not significant since the significance value is $p=0.365(p>0.05)$.

Figure 4 shows the effects of femininity and masculinity dimensions on impulse buying behavior according to male respondents. 
Figure 3. Effects of Femininity and Masculinity Dimensions on Impulse Buying Behavior According to Female Respondents

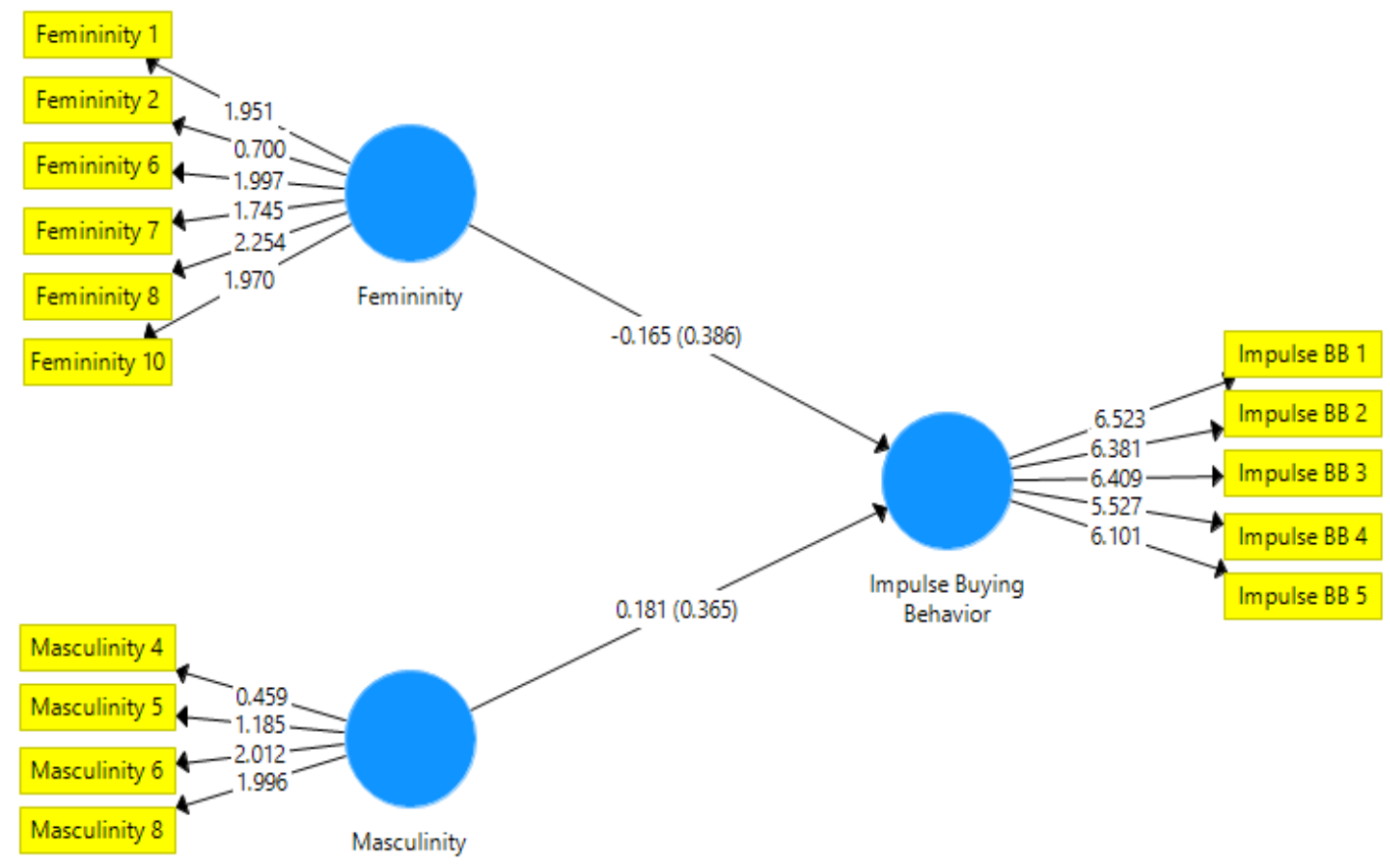

Figure 4. Effects of Femininity and Masculinity Dimensions on Impulse Buying Behavior According to Male Respondents

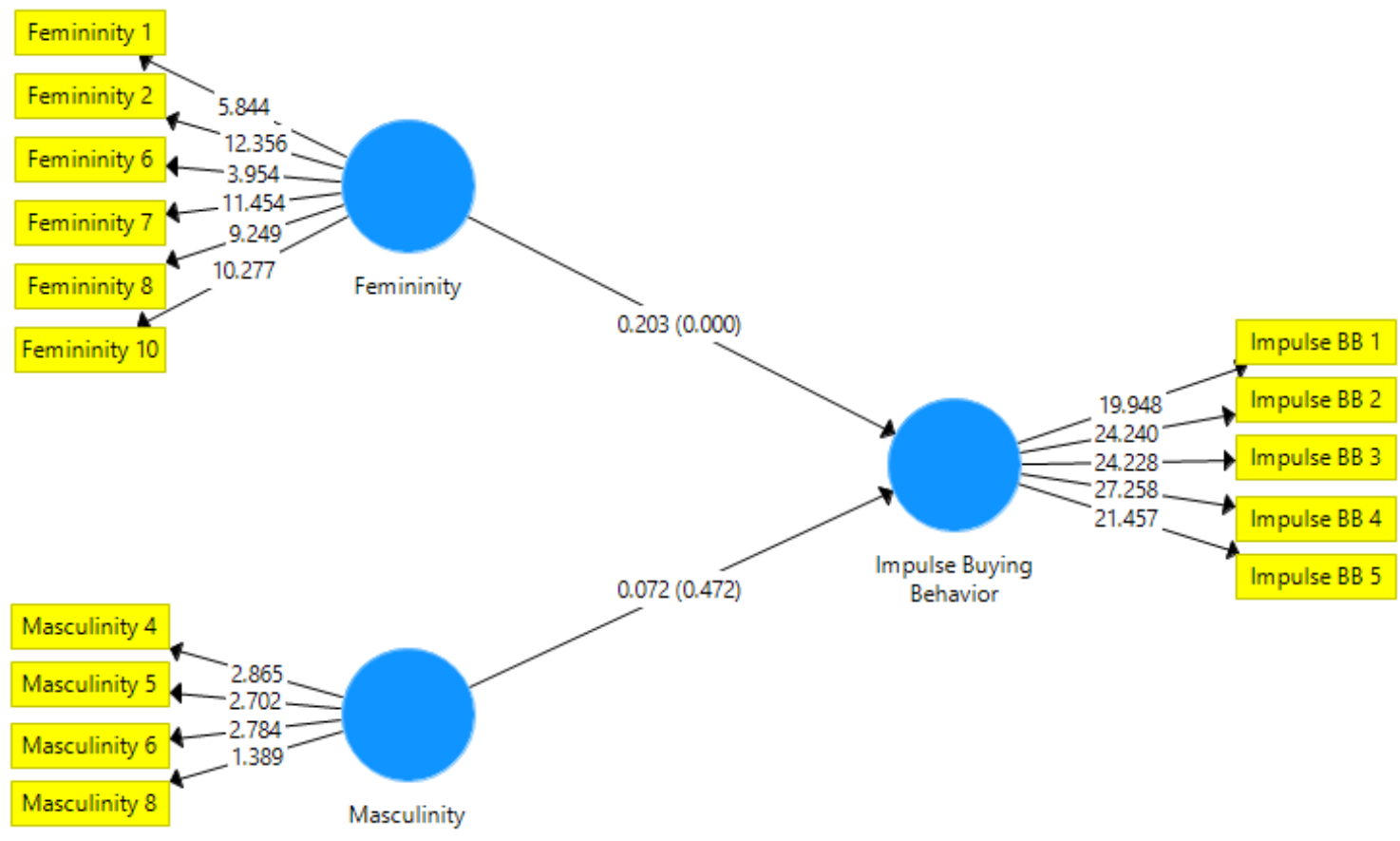


When Figure 4 is examined, it is seen that the femininity dimension has an effect on impulse buying behavior (0.203). When Table 6 is examined, it is seen that this effect is significant since the significance value is $p=0.000(p<0.05)$. Similarly, in Figure 4 , it is seen that the masculinity dimension has an effect on impulse buying behavior (0.072). When Table 6 is examined, it is seen that this effect is not significant since the significance value is $p=0.472(p>0.05)$.

Table 6. Multiple Group Analysis Results

\begin{tabular}{|c|c|c|c|c|c|c|c|c|c|}
\hline 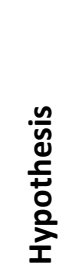 & Paths & 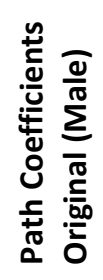 & 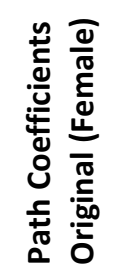 & 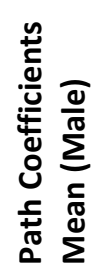 & 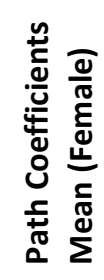 & 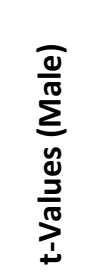 & 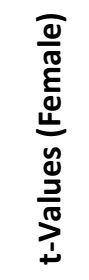 & 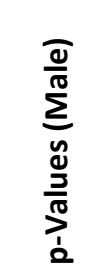 & 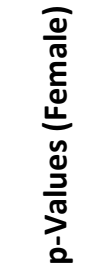 \\
\hline $\mathrm{H}_{3 \mathrm{a}}$ & $\begin{array}{c}\text { Femininity } \rightarrow \text { Impulse Buying } \\
\text { Behavior }\end{array}$ & 0.203 & -0.165 & 0.226 & -0.094 & 4.083 & 0.867 & 0.000 & 0.386 \\
\hline $\mathbf{H}_{3 \mathrm{~b}}$ & $\begin{array}{c}\text { Masculinity } \rightarrow \text { Impulse Buying } \\
\text { Behavior }\end{array}$ & 0.072 & 0.181 & 0.082 & 0.088 & 0.719 & 0.906 & 0.472 & 0.365 \\
\hline
\end{tabular}

The differences between the path coefficients and the significance levels of these differences are shown in Table 7 below.

Table 7. The Differences between Male and Female Path Coefficients

\begin{tabular}{|c|c|c|c|c|c|}
\hline Hypothesis & Paths & $\begin{array}{c}\text { Path } \\
\text { Coefficients- } \\
\text { diff } \\
\text { (Male - } \\
\text { Female) }\end{array}$ & $\begin{array}{c}\text { t-Value } \\
\text { (Male - } \\
\text { Female) }\end{array}$ & $\begin{array}{c}\text { P-Value } \\
\text { (Male - } \\
\text { Female) }\end{array}$ & Results \\
\hline $\mathrm{H}_{3 \mathrm{a}}$ & $\begin{array}{c}\text { Femininity } \rightarrow \text { Impulse Buying } \\
\text { Behavior }\end{array}$ & 0.368 & 2.139 & 0.033 & Accepted \\
\hline $\mathrm{H}_{3 \mathrm{~b}}$ & $\begin{array}{c}\text { Masculinity } \rightarrow \text { Impulse Buying } \\
\text { Behavior }\end{array}$ & 0.109 & 0.521 & 0.603 & Rejected \\
\hline
\end{tabular}

When the above table 7 is examined, it is seen that the difference between path coefficients in terms of biological sex is in the $\mathrm{H}_{3 a}$ hypothesis. Since the significance value of this hypothesis was $p=0.033(p<0.05)$, this hypothesis was accepted.

\subsection{Conclusion and Suggestions}

In this study, the effect of gender identity on the consumers' impulse buying behavior and whether this effect differs significantly according to biological sex was investigated. When the research data were analyzed, it was found that the feminine gender identity had a significant and positive effect $(0.184)$ on the consumers' impulse buying behavior, whereas the masculine gender identity had no significant effect on the consumers' impulse buying behavior. Therefore it is thought that businesses should develop new strategies to increase feminine consumers' impulse buying behavior and to direct masculine consumers to impulse buying. However, gender identity dimensions account for about $4 \%$ of the consumers' impulse buying behavior. In fact, this is normally acceptable. Beyond gender identity, the consumers' impulse buying behavior is affected by many factors such as store atmospherics, sales promotions, salespersons' behaviors, pricing strategies (Tinne, 2011; Rasheed et al., 2017; Husnain et al., 2019), consumers' moods (Rook \& Gardner, 1993), demographic characteristics (Ekeng et al., 2012; Awan \& Abbas, 2015) and the literature supports this. 
When the literature is examined, it is seen that the effect of biological sex on the consumers' impulse buying behavior is generally investigated (Ekeng et al. 2012; Rana \& Tirthani, 2012; Awan \& Abbas, 2015; Gandhi et al., 2015). However, in order to explain the consumers' impulse buying behavior, it is thought that not only examining the effect of the consumers' biological sex should be sufficient, but also the consumers' gender identity should be investigated. Therefore, it is thought that this study makes an important contribution to the literature. However, the fact that the subject was widely investigated in the literature in terms of biological sex led to the idea that this study can be evaluated in terms of biological sex. Thus, it was investigated whether the effect of gender identity on the consumers' impulse buying behavior differed according to biological sex. As a result of the study, it was found that the effect of femininity and masculinity on the consumers' impulse buying behavior differed according to the biological sex of the respondents. According to this finding, males think that femininity (0.203) has an effect on the consumers' impulse buying behavior and masculinity has no effect on the consumers' impulse buying behavior. Females think that femininity and masculinity have no effect on the consumers' impulse buying behavior. These results show that only male consumers think that another gender identity is effective on impulse buying behavior. One of the most important aspects that differentiate this study from other studies is this result. This result demonstrates the importance of investigating the effect of gender identity on the consumers' impulse buying behavior in terms of biological sex. In addition, in future studies on the effect of gender identity on the consumers' impulse buying behavior, it is thought that it will be useful to investigate the moderator effect of demographic variables such as age, income, marital status, educational status as well as biological sex.

In this study, the effects of feminine and masculine gender identity on the consumers' impulse buying behavior were investigated. However, researches on gender identity have shown that the gender identity changes over time with the effect of socio-cultural changes and increases the androgynous gender identity (high femininity-high masculinity) of females and males (Heilbrun \& Schwartz, 1982; Pedersen \& Bond, 1985; Twenge, 1997). From this point of view, it is suggested that the effect of androgynous gender identity as well as the feminine and masculine gender identity on the consumers' impulse buying behavior.

In the literature, the consumers' impulse buying behavior was generally investigated in terms of a particular product, product category or brand (Han, Morgan, Kotsiopulos \& Kang-Park, 1991; Miao \& Mattila, 2013; Khuong \& Tran, 2015; Husnain \& Akhtar, 2016). In this study, the effect of gender identity on the consumers' impulse buying behavior was not investigated in terms of a specific product, product category or brand. For this reason, it is suggested that in future studies, it may be useful to examine the effect of gender identity on the consumers' impulse buying behavior by selecting a specific product, product category or brand or by comparing between products or brands. In addition, investigating the effect of gender identity on online impulse buying behavior can be presented as a suggestion for future studies.

In studies investigating the effect of gender identity on consumer behaviors, it is seen that feminine consumers prefer feminine products or brands and masculine consumers prefer masculine products or brands (Vitz \& Johnston, 1965; Worth et al., 1992). From this point of view, it may be suggested to investigate whether the gender identity of the consumers and the gender identity of the products or brands are compatible with the impulse buying preferences.

The data of this research were collected from consumers living in Bursa. If future researches are performed on a sample group consisting of consumers living in a different city, all Turkey or a different country or on a larger sample group, different results can be obtained. Therefore, the scope of future researches can be differentiated from these aspects.

\section{References}

Aiken, L. R. (1963). The relationship of dress to selected measures of personality in undergraduate women. The Journal of Social Psychology, 59(1), 119-128.

Ali, F., Amin, M., \& Cobanoglu, C. (2016). An integrated model of service experience, emotions, satisfaction, and price acceptance: An empirical analysis in the Chinese hospitality industry. Journal of Hospitality Marketing \& Management, 25(4), 449-475. 
Ali, F., Rasoolimanesh, S. M., Sarstedt, M., Ringle, C. M., \& Ryu, K. (2018). An assessment of the use of partial least squares structural equation modeling (PLS-SEM) in hospitality research. International Journal of Contemporary Hospitality Management, 30(1), 514-538.

Allison, N. K., Golden, L. L., Mullet, G. M., \& Coogan, D. (1980). Sex-typed product images: The effects of sex, sex role self-concept, and measurement implications. Advances in Consumer Research, 7(1), 604-609.

Akagün Ergin, E., \& Özdemir Akbay, H. (2011). Giyim ve gıda ürünleri kategorilerinde tüketicilerin plansız satın alma davranışları üzerine bir araştırma. Afyon Kocatepe Üniversitesi Iktisadi ve Idari Bilimler Fakültesi Dergisi, 13(2), 275-292.

Awan, A. G., \& Abbas, N. (2015), Impact of demographic factors on impulse buying behavior of consumers in MultanPakistan. European Journal of Business and Management, 7(22), 96-105.

Beatty, S. E., \& Ferrell, M. E. (1998). Impulse buying: Modeling its precursors. Journal of Retailing, 74(2), $169-191$.

Bem, S. L. (1974). The measurement of psychological androgyny. Journal of Consulting and Clinical Psychology, 42(2), 155-162

Bem, S. L. (1977). On the utility of alternative procedures for assessing psychological androgyny. Journal of Consulting and Clinical Psychology, 45(2), 196-205.

Bem, S. L. (1981). Bem sex-role inventory: Professional manual. Palo Alto: Consulting Psychologists Press.

Clover, V. T. (1950). Relative importance of impulse buying in retail stores. Journal of Marketing, 25(July),66-70.

Cohen, J. (1988). Statistical power analysis for the behavioral sciences (2nd Edition). USA: Lawrence Erlbaum Associates.

Çabuk, S., \& Köksal Araç, S. (2013). Psikografik bir pazar bölümlendirme değişkeni olarak cinsiyet kimliği: Tüketim araştırmalarında cinsiyet kimliği kavramının incelenmesi. Çukurova Üniversitesi Sosyal Bilimler Enstitüsü Dergisi, 22(2), 27-40.

Ekeng, A. B., Lifu, F. L., \& Asinya, F. A. (2012). Effect of demographic characteristics on consumer impulse buying among consumers of Calabar Municipality, Cross River state. Academic Research International, 3(2), 568-574.

Fischer, E., \& Arnold, S. J. (1990). More than a labor of love: Gender roles and Christmas gift shopping. Journal of Consumer Research, 17(3), 333-345.

Fornell, C., \& Larcker, D. F. (1981). Evaluating structural equation models with unobservable variables and measurement error. Journal of Marketing Research, 18(1), 39-50.

Gandhi, A., Vajpayee, A., \& Gautam, D. (2015). A Study of impulse buying behavior and factors influencing it with reference to beverage products in retail stores. International Journal of Management, https://www.sibm.edu/pdf/samvad8/impulse.pdf, (10.01.2019).

Garson, G. D. (2016). Partial least squares: Regression and structural equation model. USA (Asheboro): Statistical Associates Publishing.

Gentry, J. W., \& Doering, M. (1979). Sex role orientation and leisure. Journal of Leisure Research, 11, 102-111.

Ghani, U., \& Jan, F. A. (2011). An exploratory study of the impulse buying behaviour of urban consumers in Peshawar. International Conference on Business and Economics, 1, 157-159.

Gill, S., Stockard, J., Johnson, M., \& Williams, S. (1987). Measuring gender differences: The expressive dimension and critique of androgyny scales. Sex Roles, 17(7/8), 375-400.

Golden, L. L., Allison, N., \& Clee, M. (1979). The role of sex role self-concept in masculine and feminine product perceptions. Advances in Consumer Research, 6(1), 599-605.

Graa, A., \& Dani-Elkebir, M. (2012). Application of stimulus \& response model to impulse buying behavior of Algerian consumers. Serbian Journal of Management, 7(1), 53-64.

Gudonaviciene, R., \& Alijosiene S. (2015). Visual merchandising impact on impulse buying behaviour. Procedia - Social and Behavioral Sciences, 213, 635-640.

Gunawan, M. P. (2016). Impulse buying and hedonic consumption behaviour on three Indonesian ethnicities. http://ejournal.uajy.ac.id/10421/1/Journal.pdf, (10.03.2019).

Hair, J. F., Black, W.C., Babin, B. J., \& Anderson, R. E. (2014). Multivariate data analysis (7th ed.). Essex: Pearson.

Hair, J. F., Hult, G. T. M., Ringle, C. M., \& Sarstedt, M. (2017). A primer on partial least squares structural equation modeling (PLS-SEM) (2nd ed.). Thousand Oaks: Sage Publications.

Han, Y. K., Morgan, G. A., Kotsiopulos, A., \& Kang-Park, J. (1991). Impulse buying behavior of apparel purchases. Clothing and Textiles Research Journal, 9(3), 15-21. 
The Effect of Gender Identity on Consumers' Impulse Buying Behavior and The Moderating Role of Biological Sex

Heilbrun, A. B., \& Schwartz, H. L. (1982). Sex-gender differences in level of androgyny. Sex Roles, 8(2), 201-214.

Henseler, J., Ringle, C. M., \& Sarstedt, M. (2015). A new criterion for assessing discriminant validity in variance-based structural equation modeling. Journal of the Academy of Marketing Science, 43(1), 115-135.

Henseler, J. (2017). Partial Least Squares Path Modeling (Editor: Leeflang et al). In Advanced Methods For Modeling Markets, International Series in Quantitative Marketing, Springer International Publishing, 361-381.

Husnain, M., \& Akhtar, M. W. (2016). Impact of branding on impulse buying behavior: Evidence from FMCG'S sector Pakistan. International Journal of Business Administration, 7(1), 59-68.

Husnain, M., Rehman, B., Syed, F., \& Akhtar, M. W. (2019). Personal and in-store factors influencing impulse buying behavior among generation $Y$ consumers of small cities. Business Perspectives and Research, 7(1), 92-107.

Jaffe, J., \& Berger, P. D. (1988). Impact on purchase intent of sex-role identity and product positioning. Psychology \& Marketing, 5(3), 259-271.

Kacen, J. J. (2000). Girrrl power and boyyy nature: The past, present, and paradisal future of consumer gender identity. Marketing Intelligence and Planning Journal, 18(6/7), 345-355.

Kahle, L. R., \& Homer, P. (1985). Androgyny and midday mastication: Do real men eat quiche? Advances in Consumer Research, 12, 242-246.

Khan, N., Hui, L. H., Chen, T. B., \& Hoe, H. Y. (2016). Impulse buying behaviour of generation $Y$ in fashion retail. International Journal of Business and Management, 11(1), 144-151.

Khuong, M. N., \& Tran, T. B. (2015). Factors affecting impulse buying toward fashion products in Ho Chi Minh city - A mediation analysis of hedonic purchase. International Journal of Trade, Economics, and Finance, 6(4), 223-229.

Kılıçer, T., Boyraz, E. \& Tüzemen, A. (2016). Kadın, erkek, ya da? Hediye satın alma davranışında cinsiyet kimliği rolünün etkisi. Ege Akademik Bakıs Dergisi, 16(1), 121-133.

Martin, B. A. S., \& Gnoth, J. (2009). Is the Marlboro man the only alternative? The role of gender identity and selfconstrual salience in evaluations of male models. Market Lett, 20, 353-367.

Mehta, M. P., \& Chugan, P. K. (2013). The ımpact of visual merchandising on ımpulse buying behaviour of consumer: A case from central mall of Ahmedabad India. Universal Journal of Management, 1(2), 76-82.

Miao L., \& Mattila A. S. (2013). Impulse buying in restaurant food consumption. Journal of Foodservice Business Research, 16(5,) 448-467.

Muruganantham, G., \& Bhakat, R. S. (2013). A review of impulse buying behavior. International Journal of Marketing Studies, 5(3), 149-160.

Özgüven Tayfun, N. (2015). Market alışverişlerinde plansız satın alma davranışında demografik farklılığı belirlemeye yönelik bir araştırma. Selçuk Üniversitesi Sosyal Bilimler Enstitüsü Dergisi, 34, 87-94.

Özkan, T., \& Lajunen, T. (2005). Masculinity, femininity, and the Bem sex role inventory in Turkey. Sex Roles, 52(1/2), 103-110.

Palan, K. M. (2001). Gender identity in consumer behavior research: A literature review and research agenda. Academy of Marketing Science, (10), 1-26.

Palan, K. M., Areni, C. S., \& Kiecker, P. (2001). Gender role incongruency and memorable gift exchange experiences. Advances in Consumer Research, 28, 51-57.

Pedersen, D. M., \& Bond, B. L. (1985). Shifts in sex-role after a decade of cultural change. Psychological Reports, 57, 4348.

Peng, D. X., \& Lai, F. (2012). Using partial least squares in operations management research: A practical guideline and summary of past research. Journal of Operations Management, 30(6): 467-480.

Pryzgoda, J., \& Chrisler, J. C. (2000). Definitions of gender and sex: The subtleties of meaning. Sex Roles, 43(7/8), 553569.

Rana, S., \& Tirthani, J. (2012). Effect of education, income, and gender on impulsive buying among Indian consumer an empirical study of readymade garment customers. Indian Journal of Applied Research, 1(12), 145-146.

Rasheed, A., Yaqup, R. M. S., \& Baig, F. J. (2017). Factors affecting impulse buying behaviors in shopping malls: Evidence from Bahawalpur region, Pakistan. Journal of Marketing and Consumer Research, 39, 1-20.

Ringle, C. M., Wende, S., \& Becker, J. M. (2015). SmartPLS 3. Boenningstedt: SmartPLS GmbH. http://www. smartpls.com, (04.01.2019).

Rook, D. W. (1987). The buying impulse. The Journal of Consumer Research, 14(2), 189-199. 
Rook, D. W., \& Fisher, R. J. (1995). Normative influences on impulsive buying behavior. The Journal of Consumer Research, 22(3), 305-313.

Rook, D. W., \& Gardner, M. P. (1993). In the mood: Impulse buying's affective antecedents. Research in Consumer Behavior, 6(7), 1-28.

Rook, D. W., \& Hoch, S. J. (1985), Consuming impulses. Advances in Consumer Research, 12, 23-27.

Sangalang, R. A., Siochi, J., \& Plaza, M. (2017). Factors influencing consumers' impulse buying behavior in the fifth district of Cavite. DLSU Research Congress 2017, June, 1-6.

Sarstedt, M., Ringle, C. M., \& Hair, J. F. (2017). Partial least squares structural equation modeling (eds. C. Homburg et al.). Handbook of Market Research, Springer International Publishing, 1-40.

Spence, J. T., Helmreich, R., \& Stapp, J. (1975). Ratings of self and peers on sex role attributes and their relation to selfesteem and conceptions of masculinity and femininity. Journal of Personality and Social Psychology, 32, 29-39.

Spence, J. T. (1984). Masculinity, femininity and gender-related traits: A conceptual analysis and critique of current research. Progress in Experimental Personality Research, 13, 1-97.

Stern, H. (1962). The significance of impulse buying today. Journal of Marketing, 26(2), 59- 62.

Stern, B. B. (1988), Sex-role self-concept measures and marketing: A research note. Psychology \& Marketing, 5(1), 8599.

Stets, J. E. \& Burke, P. J. (2000). Femininity/masculinity (Eds. Edgar F. Borgatta \& Rhonda J. V. Montgomery). Encyclopedia of Sociology, New York: Macmillan, 1-21.

Tinne, W. S. (2011). Factors affecting impulse buying behavior of consumers at superstores in Bangladesh. ASA University Review, 5(1), 209-220.

Torlak, Ö. \& Tiltay, M. (2010). Anlık satın alma ölçeklerinin Türk tüketicisi için uyarlanmasına yönelik bir deneme. 15. Ulusal Pazarlama Kongresi, İzmir, 406-422.

Türk, Z. (2018). Hedonik ve faydacı tüketim eğiliminin plansız satın alma davranışı üzerindeki etkisi: Bir araştırma. Uluslararası Toplum Araştırmaları Dergisi, 9(16), 854-878.

Twenge, J. M. (1997). Changes in masculine and feminine traits over time: A meta-analysis. Sex Roles, 36(5/6), 305-325.

Weun, S., Jones, M. A. \& Beatty, S. E. (1997). A parsimonious scale to measure impulse buying tendency (Eds. Pride, W. M. \& Hult, G.T.). Summer Educators' Conference, AMA Educators's Proceedings: Enhancing Knowledge Development in Marketing, Chicago, 306-307.

Weun, S., Jones, M. A., \& Beatty, S. E. (1998). the development and validation of the impulse buying tendency scale. Psychological Reports, 82(3), 1123-1133.

Worth, L. T., Smith, J., \& Mackie, D. M. (1992). Gender schematicity and preference for gender-typed products. Psychology \& Marketing, 9(1), 17-30.

Virvilaite, R., Saladiene, V., \& Bagdonaite, R. (2009). Peculiarities of impulsive purchasing in the market of consumer goods. Engineering Economics, 2, 101-109.

Vitz, P. C., \& Johnston, D. (1965). Masculinity of smokers and the masculinity of cigarette images. Journal of Applied Psychology, 49(3), 155-159.

Yağcı, M. İ., \& İlarslan, N. (2010). Reklamların ve cinsiyet kimliği rolünün tüketicilerin satın alma davranışları üzerindeki etkisi. Doğuş Üniversitesi Dergisi, 11(1), 138-155.

Ye, L., \& Robertson, T. M. A. (2012). Gender identity: Does it matter for consumers' perceptions? Journal of Business Diversity, 12(3), 81-92.

Yu, C., \& Bastin, M. (2010). Hedonic shopping value and impulse buying behavior in transitional economies: A symbiosis in the mainland China marketplace. Journal of Brand Management, 18(2), 105-114. 
This Page Intentionally Left Blank 